\title{
Moose Foraging in the Temperate Forests of Southern New England
}

\section{Citation}

Faison, Edward K., Glenn Motzkin, David R. Foster, and John E. McDonald. 2010. Moose Foraging in the Temperate Forests of Southern New England. Northeastern Naturalist 17 (1) (March): 118. doi:10.1656/045.017.0101.

\section{Published Version}

doi:10.1656/045.017.0101

\section{Permanent link}

http://nrs.harvard.edu/urn-3:HUL.InstRepos:30687088

\section{Terms of Use}

This article was downloaded from Harvard University's DASH repository, and is made available under the terms and conditions applicable to Other Posted Material, as set forth at http:// nrs.harvard.edu/urn-3:HUL.InstRepos:dash.current.terms-of-use\#LAA

\section{Share Your Story}

The Harvard community has made this article openly available.

Please share how this access benefits you. Submit a story.

\section{Accessibility}




\title{
Moose Foraging in the Temperate Forests of Southern New England
}

\author{
Edward K. Faison ${ }^{1,2, *}$, Glenn Motzkin ${ }^{1}$, David R. Foster ${ }^{1}$, \\ and John E. McDonald ${ }^{3}$
}

\begin{abstract}
Moose have recently re-colonized the temperate forests of southern New England, raising questions about this herbivore's effect on forest dynamics in the region. We quantified Moose foraging selectivity and intensity on tree species in relation to habitat features in central Massachusetts. Acer rubrum (Red Maple) and Tsuga canadensis (Eastern Hemlock) were disproportionately browsed; Pinus strobus (White Pine) was avoided. Foraging intensity correlated positively with elevation, distance to development, and watershed type and negatively with time since forest harvest, explaining $26 \%$ of the variation. Moose may interact with forest harvesting to contribute to a decline in Red Maple and Eastern Hemlock and an increase in White Pine in intensively browsed patches. Nonetheless, foraging impacts may diminish over time, as increasing temperatures and sprawling development increasingly restrict suitable Moose habitat.
\end{abstract}

\section{Introduction}

Large herbivores - often interacting with climate, fire, and human disturbance-can profoundly shape vegetation communities (McNaughton 1988, Zimov et al. 1995). Megafaunal effects are particularly strong in ecotones where climate is conducive to more than one vegetation type and foraging and trampling disturbances can shift vegetation toward one type or the other (Scholes and Archer 1997, Zimov et al. 1995). In forested biomes, persistent and rapid tree regeneration and low densities of browsing mammals typically preclude large vegetation shifts by herbivores (e.g., from forest to grassland; Forsyth 1985, Marks 1983); however, large mammals can still have important effects on species composition and biodiversity, tree density, successional pathways, and nutrient cycling in forests (Cote et al. 2004, Pastor et al. 1988).

Since the late 1980s, Alces alces L. (Moose) have recolonized their prehistorical range in southern New England (SNE) forests to approximately the July $20{ }^{\circ} \mathrm{C}$ isotherm (Foster et al. 1998, 2002). Moose populations have increased rapidly since their arrival and are currently estimated at 1000 resident animals in Massachusetts and Northern Connecticut (Massachusetts Wildlife, Westborough, MA, unpubl. data; Connecticut Department of Environmental Protection, Hartford, CT, unpubl. data). Recent range expansions and recolonizations of Moose have also occurred in other parts of

\footnotetext{
${ }^{1}$ Harvard Forest, Harvard University, 324 North Main Street, Petersham, MA 01366. ${ }^{2}$ Current address - Highstead, PO Box 1097, Redding, CT. ${ }^{3}$ US Fish and Wildlife Service, 300 Westgate Center Drive, Hadley, MA 01035-9589. *Corresponding author - efaison@highstead.net.
} 
North America, including the midwestern United States, the Rocky Mountain States, and the coastal rain forests of British Columbia (Darimont et al. 2005, Karns 1997). Although the primary factors controlling many species' southern range limits are competition and predation, temperature is the primary factor determining the Moose's southern limit (Brown et al. 1996, Karns 1997).

Moose were relatively common in $17^{\text {th }}$-century Massachusetts, but uncommon in Connecticut (Godin 1977, Trefethen 1953). Conditions at that time contrasted strikingly with the present. Predators such as Canis lupus L. (Gray Wolf), Puma concolor L. (Mountain Lion), and Native Americans were relatively common; human settlements were primarily small and dispersed; and temperatures were considerably colder under a Little Ice Age climate (Cronon 1983, Foster et al. 2004, Godin 1977). Southern New England disturbances were generally limited to localized surface fires, localized forest clearing by Native Americans, and infrequent (100-150 year intervals) canopy-replacing windstorms (Foster et al. 2004, Whitney 1994). Forest cover in southern New England included greater amounts of Fagus grandifolia Ehrhart (American Beech), Quercus spp. (oak)—especially $Q$. alba L. (White Oak) - Castanea dentata (Marshall) Borkhausen (American Chestnut), and lesser amounts of Pinus strobus L. (White Pine), Betula lenta L. (Black Birch), and especially Acer rubrum L. (Red Maple) (Abrams 1998, 2006; Hall et al. 2002).

Fires have been actively suppressed in SNE since the early $20^{\text {th }}$ century (Whitney 1994). Since the early 1800s, average temperatures have warmed by about $1.5{ }^{\circ} \mathrm{C}$, a trend particularly pronounced in the winter months; and human development has increased dramatically in the region, reducing the suitable habitat for the boreal-adapted Moose (Foster et al. 2004, Keim and Rock 2001). However, in the past several decades, widespread low-intensity logging of sawtimber-sized White Pine and Quercus rubra L. (Red Oak) has created patches of increased regeneration (Kittredge et al. 2003, McDonald et al. 2006). Logging combined with the extirpation of a chief predatorthe Gray Wolf-and a ban on Moose hunting have potentially enhanced the quality of the remaining habitat in this region, at least in the short term (Telfer 1984, Thompson and Stewart 1997).

Due to the early extirpation of Moose from most of its temperate forest range, there is almost no information about their habitat selection or foraging behavior in the mixed hardwood-White Pine-Tsuga canadensis L. (Carriere) (Eastern Hemlock) forests typical of the region. Our main objectives in this study were: (1) to quantify the selectivity and intensity of Moose foraging to anticipate possible impacts of this large herbivore on forest vegetation in Central Massachusetts and (2) to identify habitat features influencing Moose foraging activity at landscape and site scales. To address these goals, we quantified species-level availability and use of woody plants in two large forested areas and evaluated browse intensity in relationship to forest characteristics, landscape features, and harvesting activity. 


\section{Field Site Description}

The Quabbin and Ware River Watershed forests in the Central Uplands of Massachusetts were selected for investigation because these undeveloped areas support the highest Moose densities in the region (an estimated 0.5 individuals $/ \mathrm{km}^{2}$ in Quabbin and 1.1 individuals $/ \mathrm{km}^{2}$ in Ware River; D. Clark, Director of Natural Resources, Quabbin/Ware River Watershed, Belchertown, MA, pers. comm.) and because they include extensive forest harvesting and considerable variation in forest composition and habitat characteristics that could influence browse patterns (Table 1, Fig. 1; McDonald et al. 2006). Both watersheds are $\geq 10 \mathrm{~km}$ from a large urban area (Table 1).

Average temperatures within $10-15 \mathrm{~km}$ of the study area are $-3.5{ }^{\circ} \mathrm{C}$ in winter and $19.6{ }^{\circ} \mathrm{C}$ in summer (Harvard Forest, unpubl. weather station data 2001-2005), values that exceed documented heat-stress thresholds for Moose in the boreal forest by $1.5{ }^{\circ} \mathrm{C}$ in winter and $5.6{ }^{\circ} \mathrm{C}$ in summer (Schwartz and Renecker 1997). Ursus americanus Pallas (Black Bear), a chief predator of Moose calves, are present in both watershed forests (Ballard and Van Ballenberghe 1997, Foster et al. 2002). Odocoileus virginianus Zimmerman (White-tailed Deer), a potential competitor and disease transmitter to Moose, occur at low densities (2-7 individuals $/ \mathrm{km}^{2}$ ) in both watersheds (Boer 1997, McDonald et al. 2007).

\section{Quabbin Watershed Forest}

The 22,000-ha Quabbin Watershed Forest $\left(42^{\circ} 17^{\prime} \mathrm{N}, 72^{\circ} 21^{\prime} \mathrm{W}\right.$; Fig. 1) is the largest tract of conservation land in southern New England (Kittredge et al. 2003). Soils are primarily till-derived and acidic, and elevations range from 116 to $382 \mathrm{~m}$, with a mean of $232 \mathrm{~m}$. Oak-pine forests predominate with lesser amounts of Eastern Hemlock, northern hardwoods, and conifer plantations (Kyker-Snowman et al. 2007). Oaks comprise 31\% of the forest's basal area, White Pine 28\%, Red Maple 13\%, Eastern Hemlock 9\%, Black Birch 5\%, Fraxinus americana L. (White Ash) 4\%, and Prunus serotina Ehrhart (Black Cherry) $<1 \%$ (Kyker-Snowman et al. 2007). The Quabbin forest is closed to public vehicles and development, but has an extensive network of unpaved roads. Moose colonized the watershed in about 1993 (B. Spencer, former chief forester, Quabbin Watershed Forest, Belchertown, MA, pers. comm.).

Table 1. Important Moose habitat characteristics of two watershed forests in central Massachusetts (Drawbridge et al. 2003, Kyker-Snowman et al. 2007)

\begin{tabular}{lrr} 
Watershed characteristics & Quabbin & Ware River \\
\hline Size (ha) & 22,000 & 9500 \\
Average elevation $(\mathrm{m})$ & 232 & 267 \\
\% conifer cover & 22 & 23 \\
\% conifer swamp & $<1$ & 4 \\
\% of land harvested since 1984 & 30 & 22 \\
Relative size of patch clearcuts & Smaller & Larger \\
\% open wetlands & 3 & 6 \\
Closest $(\mathrm{km})$ large urban area $(>150,000$ people) & 14 & 10 \\
\hline
\end{tabular}




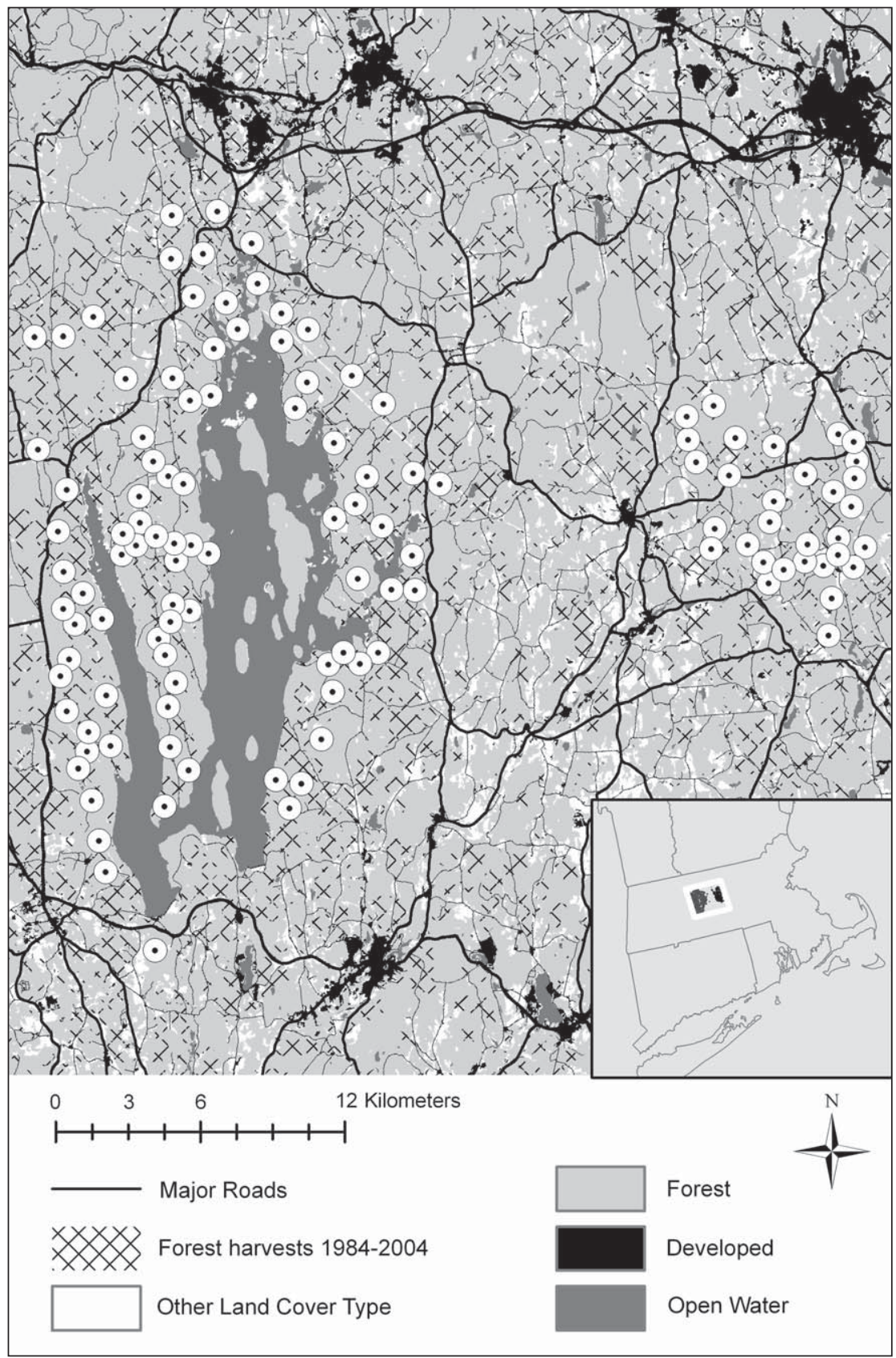

Figure 1. Central Massachusetts study area with 120 study sites (shown as white circles with black dots). Inset is the location of the two study areas, the Quabbin (left) and Ware River (right) Watershed forests, in southern New England. Data from US EPA 2001 National Land Cover Data, Massachusetts Department of Conservations and Recreation, and MassGIS. 


\section{Ware River Watershed Forest}

The 9500 -ha Ware River Watershed Forest $\left(42^{\circ} 25^{\prime} \mathrm{N}, 72^{\circ} 01^{\prime} \mathrm{W}\right.$; Fig. 1) lies $10 \mathrm{~km}$ east of the Quabbin area. The glacial till-covered uplands are interspersed with extensive valley outwash deposits and support oak-pine forests with a large proportion of forested and open wetlands (Drawbridge et al. 2003). White Pine accounts for $37 \%$ of the basal area, oaks $30 \%$, Red Maple 16\%, Eastern Hemlock 7\%, and Black Cherry 4\% (Drawbridge et al. 2003). Elevations range from 190 to $365 \mathrm{~m}$ with a mean of $267 \mathrm{~m}$. The Ware River Watershed Forest is undeveloped but has a network of trails and unpaved roads, many of which are open to public vehicular access (Drawbridge et al. 2003). Moose colonized the Ware River about 1993 (H. Eck, chief forester, Quabbin/Ware River Watershed, Belchertown, MA, pers. comm.).

\section{Methods}

\section{Plot selection}

We established plots following a stratified-random design, stratifying by forest types and recent harvesting history. Three upland forest types (hemlock, oak-pine, and northern hardwoods) and two wetland forest types (swamp hardwoods and Picea spp. [spruce] - Abies balsamea (L.) Miller (Balsam Fir) were identified on forest-type maps for each watershed (Degraaf and Yamasaki 2001; Massachusetts Department of Conservation and Recreation, Belchertown, MA, unpubl. data). Upland areas harvested since 1984 were identified based on maps filed for all commercial harvests in Massachusetts (McDonald et al. 2006). Eight harvested and 8 unharvested sites were randomly selected in each forest type. In addition, 8 oak-pine hilltops were sampled to broaden the range of topographical positions. In cases where the vegetation and harvesting history in the field did not match the mapped cover type, the site was sampled and the designations corrected. To ensure independence of plots, sample locations were separated by a minimum distance of $700 \mathrm{~m}$, a distance greater than the average daily movements of Moose in winter (Phillips et al. 1973). We distributed 120 sample plots among the 2 watersheds in approximate proportion to their forest area (Fig. 1).

\section{Vegetation surveys}

Each study site consisted of two $100-\mathrm{m}^{2}$ circular plots for sampling trees, tall shrubs, and browsing activity. Species and DBH were recorded for all trees $>2.5 \mathrm{~cm} \mathrm{DBH}$, and all tall shrubs greater than $1.8 \mathrm{~m}$ high were recorded by species. In a nested $10-\mathrm{m}^{2}$ circular subplot within each $100-\mathrm{m}^{2}$ plot, all tree stems $<2.5 \mathrm{~cm}$ DBH were recorded by species to determine seedling density and composition (Degraaf and Yamasaki 2001, Higgins et al. 1996). The centers of the two $100-\mathrm{m}^{2}$ plots were $30 \mathrm{~m}$ apart, and data from the 2 subplots were summed. 


\section{Moose foraging surveys}

At each site, Moose foraging was assessed on trees and shrubs. To distinguish Moose from White-tailed Deer foraging, we only recorded browse above $1.8 \mathrm{~m}$, the approximate height limit for year-round deer foraging (Curtis and Sullivan 2001). Moose forage at all heights between 0-3 m, but feeding trials have shown that, on $>80 \%$ of deciduous tree species, they consume most browse between 1.5 and $2.5 \mathrm{~m}$ (Bergstrom and Danell 1986). We assumed that recording browse above $1.8 \mathrm{~m}$ would exclude most deer browse but capture the predominant foraging activity of Moose; however, we recognized that in recently harvested areas this sampling system would not capture Moose browsing on low stump sprouts.

In each $100-\mathrm{m}^{2}$ plot, all woody stems with live twigs between 1.8 and $3.0 \mathrm{~m}$ and rooted in the plot were recorded by species, and presence/absence of browsing was noted. Only stems that were unequivocally browsed (i.e., torn and ragged) were recorded as "yes", and no distinction was made between recent and old browsing; thus, our browsing surveys likely reflected a browsing history that extended back months and even years (McInnes et al. 1992). Moose also strip bark from the trunks of saplings and pole-sized trees and walk on or pull down small trees to browse the nutritious leading shoots, breaking stems (Schwartz and Renecker 1997). We noted saplings broken along the major stem (with browsed leading shoots) and recorded bark-stripped stems $>1.8 \mathrm{~m}$ high. Moose predominantly feed on leaves of deciduous woody plants and aquatic vegetation in summer and on twigs and bark in winter and early spring (Renecker and Schwartz 1997). Therefore, our data likely captured predominantly late fall to early spring foraging.

\section{Foraging-intensity index}

To quantify the level of impact by Moose at each site, we developed a foraging-intensity index that combined three variables: browsing, bark stripping, and stem breakage. Moose are capable of impacting woody plants up to $6 \mathrm{~cm} \mathrm{DBH}$ by pulling down and breaking the stem and by browsing terminal shoots (Renecker and Schwartz 1997). Above $6 \mathrm{~cm}$ $\mathrm{DBH}$, trees are too large for Moose to pull down. Although Moose regularly browse lower branches of larger trees, this likely has minimal impact on the tree, and we therefore restricted our analysis of browse to stems $\leq 6$ $\mathrm{cm}$ DBH. Moose can, however, impact larger trees by bark stripping and are therefore able to affect forest communities from the seedling layer up into the canopy (Miquelle and Van Ballenberghe 1989). With this in mind, at each site, we summed the proportion of stems $\leq 6 \mathrm{~cm}$ DBH browsed, the proportion of stems $\leq 6 \mathrm{~cm} \mathrm{DBH}$ broken, and the proportion of trees $>2.5$ $\mathrm{cm}$ DBH bark-stripped. We then divided this sum by 3 in order to express the index relative to 100 . We limited index calculations to sites with $\geq 4$ available stems per category to avoid spuriously high or low proportions that might result from very small samples. 


\section{Explanatory variables}

Telfer (1984) outlined major habitat features influencing Moose distribution, which include climate, landform, vegetation, and animal communities (including humans). Based on these habitat features, we selected 6 predictor variables (five continuous and one categorical) for analysis in relation to Moose foraging intensity: elevation, solar radiation (hillshade), time since forest harvest, distance to development and major roads, "watershed" (i.e., Ware River or Quabbin), and Eastern Hemlock sapling density. Elevation is inversely related to winter temperature in central Massachusetts, and Moose begin to show winter heat stress at temperatures similar to January averages for central Massachusetts (Foster et al. 1998, Kanda et al. 2005, Schwartz and Renecker 1997). Hillshade is derived from an analysis performed with ArcGIS 9.2 to provide a proxy for relative radiation load using winter altitudes and azimuths for the town of Barre, MA (US Naval Observatory 2008). Time since harvest had a maximum value of 22 years because forest-cutting plans were not filed prior to the 1983 Massachusetts Forest Cutting Practices Act (McDonald et al. 2006). Distance to development/major roads was also calculated with ArcGIS, and "developed" land included residential, industrial, commercial, transportation, waste disposal, and recreation sites, but was primarily residential development in our study area. "Major" roads did not include unpaved forest roads. A maximum distance of $500 \mathrm{~m}$ was used for this variable, as wildlife is generally influenced by development up to this distance at a site scale (Duerksen et al. 1996). The categorical variable "watershed" was related to broader landscape features relevant to Moose habitat, including percentage of open wetlands, percentage of conifer swamps, and relative size of patch clear cuts (Table 1). Lastly, Eastern Hemlock sapling density reflected the number of Eastern Hemlock stems $(>1.8 \mathrm{~m}$ high and $\leq 6$ $\mathrm{cm} \mathrm{DBH}$ ) at each site.

\section{Statistical analysis}

Multiple linear regression was used to analyze foraging intensity (dependent variable) in relation to six explanatory variables. We examined correlation coefficients for the 6 variables, and none of them were significantly correlated $(R<0.18, P>0.08$; Table 2$)$, which increased the

Table 2. Correlation coefficients $(R)$ of predictor variables entered into multiple regression and stepAIC model.

\begin{tabular}{lccccc} 
& \multicolumn{2}{c}{$\begin{array}{c}\text { Distance to } \\
\text { Harvest } \\
\text { age }\end{array}$} & $\begin{array}{c}\text { development } \\
\text { /roads }\end{array}$ & Watershed Hillshade Elevation & $\begin{array}{c}\text { Hemlock } \\
\text { Saplings }\end{array}$ \\
\hline Hariable & 0.015 & 0.127 & 0.009 & -0.081 & 0.038 \\
Distance to development/roads & & 0.069 & 0.012 & -0.015 & 0.001 \\
Landscape & & 0.081 & 0.178 & 0.145 \\
Hillshade & & & 0.077 & 0.041 \\
Elevation & & & 0.166 \\
Eastern Hemlock saplings ${ }^{1}$ & & & & \\
${ }^{1}$ Density of Eastern Hemlock saplings $(\geq 1.8 \mathrm{~m} \mathrm{high,} \leq 6 \mathrm{~cm} \mathrm{DBH})$ at each site. & & \\
\hline
\end{tabular}


reliability of the final model (Gotelli and Ellison 2004, Graham 2003). To further test the reliability of the coefficients obtained from the multiple regression analysis, we performed a "stepAIC" (both directions) with Akaike's information criterion (AIC) to select the best model from the predictor variables. We used chi-square tests to examine browse selectivity among individual tree species. Despite using multiple comparisons, we chose not to use Bonferroni adjustments, which are deemed excessively conservative by Gotelli and Ellison (2004). We did, however, use Yates continuity corrections for each test (Gotelli and Ellison 2004). Tree species are presented as "selected" or "avoided" based on whether there was a significant difference between their availability and use. We used analysis of variance (ANOVA) to compare foraging intensities among the 5 forest types. All data were arc-sine or log transformed to achieve normality, and all analyses were performed with S-Plus 8.0 software (Insightful Corporation, Seattle, WA).

\section{Results}

At sites where Moose sign was observed, the average percentage of stems browsed was 36\% at Ware River and 18\% at Quabbin. Overall, only 3\% of our sites were intensively browsed ( $>75 \%$ of stems browsed). Bark stripping occurred on $1 \%$ of trees $>2.5 \mathrm{~cm} \mathrm{DBH}$ and $<30 \mathrm{~cm} \mathrm{DBH}$, and $91 \%$ of the incidences occurred at Ware River sites. Red Maple accounted for $98 \%$ of bark-stripped stems, and $2 \%$ of our sites were intensively stripped $(>50 \%$ of stems stripped). Stem breakage by Moose occurred on $1 \%$ of all small saplings $(2.5-6.0 \mathrm{~cm} \mathrm{DBH})$. Among major tree species $(\leq 6.0 \mathrm{~cm} \mathrm{DBH})$ in harvested sites, White Pine was avoided $(P<0.001)$, and Red Maple $(P<$ $0.01)$ and total hardwoods $(P<0.001)$ were selected for browsing (Table 3$)$. In unharvested sites, Eastern Hemlock $(P<0.05)$ was selected, and White Pine was avoided $(P<0.01$; Table 4$)$. Red Maple was selected for bark stripping in both harvested and unharvested forests (Tables 3 and 4). Hemlock saplings were broken in greater proportion to their availability in unharvested areas and overall ( $P<0.01$; Tables 4 and 5), while Betula populifolia Marsh (Gray Birch) saplings were disproportionately broken in harvested sites $(P<0.001$; Tables 3-5).

\section{Foraging intensity}

One hundred sites met the inclusion criteria of the foraging-intensity index, and index values ranged from $0-0.40$ across these sites. Five of the 100 sites were excluded from the subsequent multiple regression and stepAIC analysis because of missing values. The multiple regression model included three significant variables $(P<0.05)$ that explained $26 \%$ of the variation in foraging intensity: elevation (positive; $P=0.004$ ), watershed (Ware River; $P=0.02$ ), and time since harvest (negative; $P=0.03$ ); distance to development was marginally significant (positive; $P=0.05$ ). StepAIC analysis produced a final model with the same four explanatory variables as 
predictors of Moose foraging intensity. Lastly, foraging intensities did not differ across forest types $(P=0.84)$.

\section{Discussion}

\section{Selective foraging and long-term forest dynamics}

Moose selected Eastern Hemlock, Red Maple, and total hardwood browse and avoided White Pine. Moose also stripped Red Maple saplings and poles and broke Eastern Hemlock and Gray Birch saplings in greater proportion to their availability (Tables 3-5). White Pine has increased in the region since the time of European settlement (Hall et al. 2002), in part as a result of selective browsing by domestic cattle in late $19^{\text {th }}$ - and early $20^{\text {th }}$-century abandoned fields (Bromley 1935, Fisher 1918). Selective browsing by Moose may continue to promote the increase of White Pine in this landscape.

Red Maple has increased in the region as a result of $20^{\text {th }}$-century fire suppression, selective harvesting of oaks, and perhaps increased precipitation (Abrams 1998, Hall et al. 2002, Keim and Rock 2001). Selection of Red Maple twigs and bark by Moose and reductions of Red Maple seedlings in

Table 3. Moose selection and avoidance of trees in harvested sites of both watershed forests. Chi-square values indicate the degree of difference between used and available stems.

\begin{tabular}{|c|c|c|c|c|c|}
\hline Unharvested sites & $n$ & $\%$ used & $\%$ available & $\chi^{2}$ & Choice $^{4}$ \\
\hline \multicolumn{6}{|l|}{$\overline{\text { Browsing }^{1}}$} \\
\hline Red Maple & 120 & 30 & 17 & $16.7 * *$ & \multirow[t]{3}{*}{$\mathrm{S}$} \\
\hline Black Birch & 176 & 25 & 25 & 0.01 & \\
\hline $\begin{array}{l}\text { Carpinus caroliniana Walt. } \\
\text { (American Hornbeam) }\end{array}$ & 10 & 1 & 1 & 0.15 & \\
\hline American Chestnut & 12 & 3 & 2 & 1.50 & \multirow{7}{*}{ A } \\
\hline White Ash & 19 & 0.4 & 3 & 4.30 & \\
\hline White Pine & 212 & 9 & 31 & $43.1 * * *$ & \\
\hline Black Cherry & 58 & 14 & 8 & 5.40 & \\
\hline Red Oak & 28 & 4 & 4 & 0.12 & \\
\hline Eastern Hemlock & 14 & 3 & 2 & 0.31 & \\
\hline Other trees & 43 & 10 & 6 & 3.10 & \\
\hline Hardwoods & 465 & 89 & 67 & $39.1 * * *$ & $\mathrm{~S}$ \\
\hline Conifers & 227 & 11 & 33 & $39.1 * * *$ & A \\
\hline \multicolumn{6}{|l|}{ Bark stripping ${ }^{2}$} \\
\hline Red Maple & 118 & 100 & 21 & $18.0 * * *$ & S \\
\hline Other trees & 440 & 0 & 79 & $18.0^{* * *}$ & A \\
\hline \multicolumn{6}{|l|}{ Stem breakage ${ }^{3}$} \\
\hline Gray Birch & 5 & 33 & 2 & $24.9 * * *$ & \multirow[t]{2}{*}{ S } \\
\hline Red Oak & 16 & 33 & 6 & 7.50 & \\
\hline Other trees & 264 & 33 & 91 & $26.3^{* * *}$ & A \\
\hline \multicolumn{6}{|l|}{${ }^{1}$ Trees $\leq 6.0 \mathrm{~cm} \mathrm{DBH}}$. \\
\hline \multicolumn{6}{|l|}{${ }^{2}$ Trees $2.5-29.0 \mathrm{~cm} \mathrm{DBH}$. } \\
\hline \multicolumn{6}{|l|}{${ }^{3}$ Trees $2.5-6.0 \mathrm{~cm} \mathrm{DBH}}$. \\
\hline \multicolumn{6}{|c|}{${ }^{4}$ Choice: $\mathrm{S}=$ selected, $\mathrm{A}=$ avoided. } \\
\hline$* P<0.05, * * P<0.01, * * * P$ & & & & & \\
\hline
\end{tabular}


the region by deer (Healy 1997) suggest that Moose browsing could limit Red Maple in some areas. Winter browsing, captured by our sampling, is generally less harmful to hardwoods like Red Maple than is summer browsing (Canham et al. 1994), and bark-stripped trees often recover unless severely girdled ( $>66 \%$ of circumference; Gill 1992). Although we did not measure the percent circumference of bark wounds, we observed that most Red Maples were damaged at a level below 66\%. Nonetheless, an increased incidence of disease and stem breakage can occur at the wound site of barkstripped stems (Gill 1992, Miquelle and Van Ballenberghe 1989).

Like Balsam Fir in the boreal forests of eastern North America, Eastern Hemlock appears to be an important winter browse species for Moose in the temperate forests of SNE; Eastern Hemlock is also selected by deer in this region and has declined in the past decade due to Adelges tsugae Annand (Hemlock Woolly Adelgid) and associated salvage logging (Kittredge and Ashton 1995, Orwig et al. 2002). Moose browsing may contribute to this on-going decline and could have a bigger impact on Eastern Hemlock than on Red Maple because of Eastern Hemlock's slower growth rate than hardwoods (Kelty 1986), the generally poorer

Table 4. Moose selection and avoidance of trees in unharvested sites of both watershed forests. Chi-square values indicate the degree of difference between used and available stems.

\begin{tabular}{|c|c|c|c|c|c|}
\hline Unharvested sites & $n$ & $\%$ used & $\%$ available & $\chi^{2}$ & Choice $^{4}$ \\
\hline \multicolumn{6}{|l|}{ Browsing $^{1}$} \\
\hline Balsam Fir & 13 & 6 & 3 & 3.50 & \\
\hline Red Maple & 93 & 24 & 19 & 1.00 & \\
\hline Betula alleghaniensis Britt. (Yellow Birch) & 17 & 8 & 3 & 3.20 & \\
\hline Black Birch & 63 & 8 & 13 & 2.10 & \\
\hline American Hornbeam & 36 & 10 & 7 & 0.58 & \\
\hline White Pine & 135 & 9 & 28 & $15.30^{* *}$ & A \\
\hline White Oak & 11 & 5 & 2 & 2.80 & \\
\hline Red Oak & 17 & 4 & 3 & 0.15 & \\
\hline Quercus velutina Lam. (Black Oak) & 16 & 3 & 3 & 0.001 & \\
\hline Eastern Hemlock & 35 & 17 & 7 & $9.80 *$ & $\mathrm{~S}$ \\
\hline Other trees & 38 & 6 & 8 & 0.20 & \\
\hline Hardwoods & 295 & 68 & 60 & 1.80 & \\
\hline Conifers & 193 & 32 & 40 & 1.80 & \\
\hline \multicolumn{6}{|l|}{ Bark stripping $^{2}$} \\
\hline Red Maple & 142 & 98 & 24 & $98.00 * * *$ & $\mathrm{~S}$ \\
\hline American Chestnut & 4 & 2 & 1 & 1.40 & \\
\hline Other trees & 441 & 0 & 75 & $107.70 * * *$ & A \\
\hline \multicolumn{6}{|l|}{ Stem breakage ${ }^{3}$} \\
\hline Red Maple & 64 & 17 & 23 & 0.13 & \\
\hline Red Oak & 8 & 17 & 3 & 3.70 & \\
\hline Eastern Hemlock & 30 & 67 & 11 & $17.50 * *$ & $\mathrm{~S}$ \\
\hline Other trees & 177 & 0 & 66 & $10.00^{*}$ & A \\
\hline $\begin{array}{l}{ }^{1} \text { Trees } \leq 6.0 \mathrm{~cm} \mathrm{DBH} . \\
{ }^{2} \text { Trees } 2.5-29.0 \mathrm{~cm} \mathrm{DBH} . \\
{ }^{3} \text { Trees } 2.5-6.0 \mathrm{~cm} \mathrm{DBH} . \\
{ }^{4} \text { Choice: } \mathrm{S}=\text { selected, } \mathrm{A}=\text { avoided. } \\
{ }^{*} P<0.05,{ }^{*} P<0.01, * * * P<0.001 .\end{array}$ & & & & & \\
\hline
\end{tabular}


ability of conifers to exhibit compensatory growth to browsing (Persson et al. 2005), and Eastern Hemlock's apparent susceptibility to stem breakage (Miquelle and Van Ballenberghe 1989).

In the boreal regions of eastern North America, Moose browsing shows some parallel patterns to SNE. One dominant conifer (Balsam Fir) and a few deciduous species_Betula papyrifera Marshall (Paper Birch), Populus tremuloides Michx. (Quaking Aspen), and Populus balsamifera L. (Balsam Poplar) — are selected by Moose. A second major conifer (spruce) is avoided (Pastor et al. 1988, Thompson et al. 1992). Selective and intensive foraging in the boreal forest has shifted forest composition from early successional hardwoods to late successional spruce in some areas, speeding up forest succession and reducing available soil nitrogen (by increasing the proportion of low-nutrient spruce litter that is returned to the soil; Pastor et al. 1988, Thompson et al. 1992).

The successional implications of our foraging data are difficult to generalize. Selection by Moose of Red Maple and early successional Gray Birch in regenerating stands dominated by hardwoods may speed up succession by allowing oaks to dominate the stand more quickly than they otherwise would (Oliver and Larson 1996). However, selection of Eastern Hemlock and Red Maple and avoidance of White Pine on very moist sites could slow down succession, as Eastern Hemlock and Red Maple outgrow other species at an earlier age in moist locations and persist as late-successional

Table 5. Moose selection and avoidance of trees in all sites of both watershed forests. Chisquare values indicate the degree of difference between used and available stems.

\begin{tabular}{|c|c|c|c|c|c|}
\hline All sites & $n$ & $\%$ used & $\%$ available & $\chi^{2}$ & Choice $^{4}$ \\
\hline \multicolumn{6}{|l|}{ Browsing $^{1}$} \\
\hline Red Maple & 213 & 28 & 18 & $16.10 * *$ & $\mathrm{~S}$ \\
\hline Black Birch & 239 & 20 & 20 & 0.01 & \\
\hline White Pine & 347 & 9 & 29 & $57.20 * * *$ & $\mathrm{~A}$ \\
\hline Black Cherry & 71 & 10 & 6 & 5.40 & \\
\hline Oak spp. & 75 & 7 & 6 & 0.02 & \\
\hline Eastern Hemlock & 49 & 7 & 4 & 4.20 & \\
\hline Hardwoods & 760 & 83 & 64 & $38.00 * * *$ & $\mathrm{~S}$ \\
\hline Conifers & 420 & 17 & 36 & $38.00 * * *$ & A \\
\hline \multicolumn{6}{|l|}{ Bark stripping $^{2}$} \\
\hline Red Maple & 260 & 98 & 23 & $122.90 * * *$ & $\mathrm{~S}$ \\
\hline Other trees & 885 & 2 & 77 & $122.90 * * *$ & A \\
\hline \multicolumn{6}{|l|}{ Stem breakage $^{3}$} \\
\hline Red Maple & 121 & 9 & 21 & 0.99 & \\
\hline Oak spp. & 32 & 27 & 6 & 8.98 & \\
\hline Eastern Hemlock & 36 & 36 & 6 & $15.30 * *$ & $\mathrm{~S}$ \\
\hline Other trees & 383 & 27 & 69 & 7.60 & \\
\hline \multicolumn{6}{|l|}{${ }^{1}$ Trees $\leq 6.0 \mathrm{~cm} \mathrm{DBH}$} \\
\hline \multicolumn{6}{|l|}{${ }^{2}$ Trees $2.5-29.0 \mathrm{~cm} \mathrm{DBH}$. } \\
\hline \multicolumn{6}{|l|}{${ }^{3}$ Trees $2.5-6.0 \mathrm{~cm} \mathrm{DBH}}$. \\
\hline \multicolumn{6}{|l|}{${ }^{4}$ Choice: $\mathrm{S}=$ selected, $\mathrm{A}=$ avoided. } \\
\hline$* P<0.05, * * P<0.01, * * * P<0.001$. & & & & & \\
\hline
\end{tabular}


dominants (Oliver and Larson 1996, Spurr 1956). White Pine does occur as a less frequent, late-successional species in Central Massachusetts on dry soils (Spurr 1956). In contrast to the decline of soil fertility associated with an increase in spruce in the boreal model, an increase in White Pine in SNE would not necessarily result in a decline in soil fertility; soils beneath White Pine stands can have higher nitrogen mineralization rates than those beneath adjacent hardwood stands (Binkley and Valentine 1991).

Oaks, a valuable timber species in SNE and also producing the most important food source (acorns) for eastern forest animals (McShea and Healy 2002, University of Connecticut Cooperative Extension Service 19942008), were not selectively browsed, bark stripped, or broken by Moose. Oak seedlings, however, declined sharply in the Quabbin Reservation from deer browsing during the $20^{\text {th }}$ century (Healy 1997). Relative abundance of overstory oaks has declined across the region and most of the eastern United States since pre-settlement times, perhaps due to fire suppression and increased precipitation (Abrams 2006, Keim and Rock 2001). Oak recruitment into the sapling layer is currently very low in many areas in the eastern United States, but in southern New England, oak sapling densities are higher today than they were two decades ago (Abrams 2006, Moser et al. 2006).

\section{Foraging intensity and effect on forests}

When projecting impacts by moose to temperate forests of southern New England, it is instructive to examine how different foraging intensities by Moose and other herbivores have affected plant communities in other regions. In the boreal forests of Isle Royale, MI, tree biomass production was related to past browsing intensity. Vegetation at a site with heavy past browsing (76\% of woody stems browsed) was substantially altered-e.g., unpalatable spruce were the only trees growing above browse height, while Balsam Fir and Paper Birch were suppressed (McInnes et al. 1992, Pastor et al. 1988). In contrast, the tree species mix at a site with moderate past browsing (51\% of stems browsed) was not changed.

Shifts in community composition have been noted when $>50 \%$ of the stems of a particular tree species were bark stripped by herbivores such as White-tailed Deer and Cervus elaphus L. (Elk) (Miquelle and Van Ballenberghe 1989). Only $3 \%$ of our sites matched the $>75 \%$ browsing intensity associated with strong impacts to Isle Royale forests, and only $2 \%$ of our sites had $>50 \%$ Red Maple stems stripped. Thus, our data imply that Moose (at current population densities) may have serious impacts on forests at only scattered localities in SNE.

\section{Interactions with forest harvesting}

Foraging intensity was unrelated to forest type, but was correlated with time since forest harvesting. Moose are attracted to early seral stages of forests ( $5-15$ years) because of high stem densities, large shoots produced by stump sprouting, and high quality forage resulting from increased soil nitrogen mineralization stimulated by fire and forest harvesting (Pastor et 
al. 1988, Rea and Gillingham 2001, Renecker and Schwartz 1997). Had we sampled browsing $<1.8 \mathrm{~m}$ in height (and been able to distinguish Moose from deer browsing), we would have captured intensive browsing of low stump sprouts in recent harvests and perhaps strengthened the relationship between foraging intensity and time since harvest. This sampling limitation may account for some of the $74 \%$ unexplained variation in our multiple regression model.

With $25-30 \%$ of the forest land in central Massachusetts harvested between 1984-2003 and White Pine growing with Red Maple and other hardwoods in many regenerating cut blocks, the current rate of logging could largely determine spatial pattern and extent of Moose impacts to forest composition (McDonald et al. 2006). In the boreal zone, landscape-scale fires and large clearcuts (Delong and Tanner 1996, Hunter 1993) produce extensive areas of abundant regeneration that can reduce the impact of even very high Moose densities (Pastor et al. 1988, Peterson 1995). The small scale and intensity of Massachusetts harvests (average 15 ha; Kittredge et al. 2003) suggests that regeneration in SNE forests may be more susceptible to Moose impacts than in boreal forests.

\section{Controls over landscape-level patterns}

Foraging intensity was related to elevation and specific watershed features and suggests that in addition to recent forest harvests, thermoregulation and year-round availability of forage away from human settlements may be important controls over Moose foraging. Several aspects of the Ware River area appear to be favorable for Moose. A higher fraction of the watershed consists of coniferous forested wetlands than the Quabbin, providing Moose with cool locations during the summer and abundant tall-shrub browse (Pastor et al. 1988; Table 1). The Ware River also has twice the percentage of open wetlands than the Quabbin; these wetlands supply abundant aquatic plants (Table 1). Despite the Quabbin's greater proportion of harvested forests, the Ware River has historically been managed with larger patch clearcuts, creating larger areas of concentrated browse that allow Moose to forage with less energy expenditure (Telfer 1984).

The relationship between foraging intensity and elevation suggests that topography and thermoregulation could limit the ability of Moose to impact forests at lower elevations in the region and ultimately to spread south into the lowlands of southern New England. Microclimatic studies indicate that temperatures in the region decrease approximately $0.7-1.3{ }^{\circ} \mathrm{C}$ over an equivalent elevation rise of our study area (Kanda et al. 2005, Ross 1958), a significant amount given that Moose in the boreal forest begin to exhibit heat stress in winter at temperatures $\left(-5^{\circ} \mathrm{C}\right)$ that are below winter averages in central Massachusetts $\left(-3.5{ }^{\circ} \mathrm{C}\right.$; Harvard Forest, unpubl. weather station data 2001-2005; Schwartz and Renecker 1997). With some climate models predicting a rise in regional temperatures of $3.1-5.3{ }^{\circ} \mathrm{C}$ over the next century and the loss of forestland in Massachusetts and Connecticut accelerating over the past 30 years (Foster et al. 2005, Hurtt and Hale 2001), 
much (if not all) of the region could be rendered unsuitable for Moose by the end of the century. Suitable Moose habitat may become restricted to remote, elevated areas with abundant swamps and open wetlands, reducing the extent of their impacts to forest dynamics in this region.

Moose are unlikely to be limited by predation in SNE, as only one of their three chief predators, Black Bear, currently inhabits the region. Potential recolonization habitat for the Gray Wolf in the northeastern United States is limited to northern New England and New York (Mladenoff and Sickley 1998).

\section{Acknowledgments}

This paper is a contribution from the Harvard Forest Long-term Ecological Research Program. Funding for this project was provided by the National Science Foundation, the Anna B. Bliss Fund and Living Diorama Scholarship Fund, and the Harvard University Program for Research and Training in Ecology from the Andrew W. Mellon Foundation. Special thanks to Aaron Ellison for statistical assistance. Thanks also to Todd Fuller, Bruce Spencer, Herm Eck, Derek Beard, Thom KykerSnowman, Dan Clark, and Bill Woytek for helpful correspondence and to Josh Rapp for field assistance.

\section{Literature Cited}

Abrams, M.D. 1998. The Red Maple paradox. Bioscience 48:355-364.

Abrams, M.D. 2006. Ecological and ecophysiological attributes and responses to fire in eastern oak forests. Pp. 74-89, In M.B. Dickinson (Ed.). Fire in Eastern Oak Forests: Delivering Science to Land Managers. General Technical Report NRSP-1. US Department of Agriculture, Forest Service, Northern Research Station. Newtown Square, PA. 303 pp.

Ballard, W.B., and V. Van Ballenberghe. 1997. Predator/prey relationships. Pp. 247273, In A.W Franzmann and C.C. Schwartz (Eds.). Ecology and Management of the North American Moose. Smithsonian Institution, Washington, DC. 733 pp.

Bergstrom, R., and K. Danell. 1986. Moose winter feeding in relation to morphology and chemistry of six tree species. Alces 22:91-112.

Binkley, D., and D. Valentine. 1991. Fifty-year biogeochemical effects of Green Ash, White Pine, and Norway Spruce in a replicated experiment. Forest Ecology and Management 40:13-25.

Boer, A.H. 1997. Interspecific relationships Pp. 337-349, In A.W Franzmann and C.C. Schwartz (Eds.). Ecology and Management of the North American Moose. Smithsonian Institution, Washington, DC. 733 pp.

Bromley, S.W. 1935. The original forest types of southern New England. Ecological Monographs 5:61-89.

Brown, J.H., G.C. Stevens, and D.M. Kaufman. 1996. The geographic range: Size, shape, boundaries, and internal structure. Annual Review of Ecology and Systematics 27:597-623

Canham, C.D., J.B. McAninch, and D.M. Wood. 1994. Effects of the frequency, timing, and intensity of simulated browsing on growth and survival of tree seedlings. Canadian Journal of Forest Research 24:817-825.

Cote, S.D., T.P. Rooney, J.P. Tremblay, C. Dussault, and D.M. Waller. 2004. Ecological impacts of deer overabundance. Annual Review of Ecology, Evolution, and Systematics 35:113-147. 
Cronon, W. 1983. Changes in the Land: Indians, Colonists, and the Ecology of New England. Hill and Wang, New York, NY. 241 pp.

Curtis, P.D., and K.L. Sullivan. 2001. Wildlife damage management fact sheet: White-tailed Deer. Cornell Cooperative Extension, Ithaca, NY.

Darimont, C.T., P.C. Paquet, T.E. Reimchen, and V. Crichton. 2005. Range expansion by Moose into coastal temperate rainforests of British Columbia, Canada. Diversity and Distributions 11:235-239.

DeGraaf, R.M., and M. Yamasaki. 2001. New England Wildlife: Habitat, Natural History, and Distribution. University Press of New England, Hanover, NH. $482 \mathrm{pp}$.

Delong, S.C., and D. Tanner. 1996. Managing the pattern of forest harvest: Lessons from wildfire. Biodiversity and Conservation 5:1191-1205.

Drawbridge, S., H. Eck, B. Spencer, D. Clark, T. Kyker-Snowman, P. Church, M. Fluet, M. Hopkinson, D. Small, J. French, and J. Zimmerman. 2003. Ware River Watershed Land Management Plan 2003-2012. Massachusetts Department of Conservation and Recreation Division of Water Supply Protection, Office of Watershed Management. Boston, MA. 205 pp.

Duerksen, C. J., N.T. Hobbs, D.L. Elliot, E. Johnson, and J.R. Miller. 1996. Managing Development for People and Wildlife: A Habitat Protection Handbook for Local Governments. Clarion Associates, Denver, CO. 122 pp.

Fisher, R.T. 1918. Second-growth White Pine as related to the former uses of the land. Journal of Forestry 16:253-254.

Forsyth, A. 1985. Mammals of the American North. Camden House Publishing, Camden East, ON, Canada. 351 pp.

Foster, D.R., G. Motzkin, and B. Slater. 1998. Land-use history as long-term broadscale disturbance: Regional forest dynamics in Central New England. Ecosystems 1:96-119.

Foster, D.R., G. Motzkin, D. Bernardos, and J. Cardoza. 2002. Wildlife dynamics in a changing landscape. Journal of Biogeography 29:1337-1357.

Foster, D., G. Motzkin, J. O'Keefe, E. Boose, D. Orwig, J. Fuller, and B. Hall. 2004. The environmental and human history of New England. Pp. 43-100, In. D.R. Foster and J.D. Aber (Eds.). Forests in Time. Yale University Press, New Haven, CT. 477 pp.

Foster, D., D. Kittredge, B. Donahue, G. Motzkin, D. Orwig, A. Ellison, B. Hall, B. Colburn, and A. D'Amato. 2005. Wildlands and woodlands: A Vision for the forests of Massachusetts. Harvard Forest, Petersham, MA. 24 pp.

Gill, R.M.A. 1992. A review of damage by mammals in north temperate forests: 3 . Impact on trees and forests. Forestry 65:363-388.

Godin, A.J. 1977. Wild Mammals of New England. Johns Hopkins University Press, Baltimore, MD. 304 pp.

Gotelli, N.J., and A.M. Ellison. 2004. A Primer of Ecological Statistics. Sinauer Associates, Sunderland, MA. 510 pp.

Graham, M.H. 2003. Confronting multicollinearity in ecological multiple regression. Ecology 84:2809-2815.

Hall, B., G. Motzkin, D.R. Foster, M. Syfert, and J. Burk. 2002. Three hundred years of forest and land-use change in Massachusetts, USA. Journal of Biogeography 29:1319-1335.

Healy, W.M. 1997. Influence of deer on the structure and composition of oak forests in central Massachusetts. Pp. 249-266, In W.J. McShea, H.B. Underwood, and J.H. Rappole (Eds.). The Science of Overabundance. Smithsonian Institution, Washington, DC. 402 pp. 
Higgins, K.F., J.L. Oldemeyer, K.J. Jenkins, G.K. Clambey, and R.F. Harlow. 1996.

Vegetation sampling and measurement. Pp. 567-591, In T.A. Bookhout (Ed.). Research and Management Techniques for Wildlife and Habitat. Allen Press, Lawrence, KS. 740 pp.

Hunter, M.L. 1993. Natural fire regimes as spatial models for managing boreal forests. Biological Conservation 65:115-120.

Hurtt, G., and S. Hale. 2001. Future climates of the New England Region. Pp. 26-31, In The New England Regional assessment Group (Eds.). Preparing For a Changing Climate: The New England Regional Assessment Overview. US Global Change Research Program, University of New Hampshire, Durham, NH. 96 pp.

Kanda, L.L., T.K. Fuller, P.R. Sievert, and K.D. Friedland. 2005. Variation in winter microclimate and its potential influence on Virginia Opossum (Didelphis virginiana) survival in Amherst, Massachusetts. Urban Ecosystems 8:215-225.

Karns, P.D. 1997. Population, distribution, density, and trends. Pp. 125-139, In A.W Franzmann and C.C. Schwartz (Eds.). Ecology and Management of the North American Moose. Smithsonian Institution, Washington, DC. 733 pp.

Keim, B., and B. Rock. 2001. The New England region's changing climate. Pp. 8-17, In The New England Regional assessment Group (Eds.). Preparing For a Changing Climate: The New England Regional Assessment Overview. US Global Change Research Program, University of New Hampshire, Durham, NH. 96 pp.

Kelty, M.J. 1986. Development patterns in two hemlock-hardwood stands in southern New England. Canadian Journal of Forest Research 16:885-891.

Kittredge, D.B., and P.M.S. Ashton. 1995. Impact of deer browsing on regeneration in mixed stands in southern New England. Northern Journal of Applied Forestry 12:115-120.

Kittredge, D.B., A.O. Finley, and D.R. Foster, 2003. Timber harvesting as ongoing disturbance in a landscape of diverse ownership. Forest Ecology and Management 180:425-442.

Kyker-Snowman, T., D. Clark, H. Eck, J. French, D. Morin, R. Stone, M. Fluet, S. Campbell, D. Small, P. Lyons, and J. Zimmerman. 2007. Quabbin Reservoir Watershed system: Land management plan. 2007-2017. Massachusetts Department of Conservation and Recreation Division of Water Supply Protection, Office of Watershed Management. Boston, MA. 341 pp.

Marks, P. 1983. On the origin of the field plants of the Northeastern United States. American Naturalist 122:210-228.

McDonald, J.E., D.E. Clark, and W.A. Woytek. 2007. Reduction and maintenance of a White-tailed Deer herd in central Massachusetts. Journal of Wildlife Management 71:1585-1593.

McDonald, R.I., G. Motzkin, M.S. Bank, D.B. Kittredge, J. Burk, and D.R. Foster. 2006. Forest harvesting and land-use conversion over two decades in Massachusetts. Forest Ecology and Management 227:31-41.

McInnes, P.F., R.J. Naiman, J. Pastor, and Y. Cohen. 1992. Effects of Moose browsing on vegetation and litter of the boreal forest, Isle Royale, Michigan, USA. Ecology 73:2059-2075.

McNaughton, S.J. 1988. Large mammals and process dynamics in African ecosystems. Bioscience 38:794-800.

McShea, W.J., and W.M. Healy. 2002. Oaks and acorns as a foundation for ecosystem management. Pp. 1-9, In W.J. McShea and W.M. Healy (Eds.). Oak Forest Ecosystems: Ecology and Management for Wildlife. Johns Hopkins University Press. Baltimore, MD. 432 pp. 
Miquelle, D.G., and V. Van Ballenberghe. 1989. Impact of bark stripping by Moose on aspen-spruce communities. Journal of Wildlife Management 53:577-586.

Mladenoff, D.J., and T.A. Sickley. 1998. Assessing potential Gray Wolf restoration in the Northeastern United States: A spatial prediction of favorable habitat and potential population levels. Journal of Wildlife Management 62:1-10.

Moser, W.K., M. Hansen, W. McWilliams, and R. Sheffield. 2006. Oak composition and structure in the Eastern United States. Pp. 49-61, In M.B. Dickinson (Ed.). Fire in Eastern Oak Forests: Delivering Science to Land Managers. General Technical Report NRS-P-1. Department of Agriculture, Forest Service, Northern Research Station. Newtown Square, PA. 303 pp.

Oliver, C.D., and B.C. Larson. 1996. Forest Stand Dynamics. John Wiley and Sons, New York, NY. 520 pp.

Orwig, D.A., D.R. Foster, and D.L. Mausel. 2002. Landscape patterns of hemlock decline in New England due to the introduced Hemlock Woolly Adelgid. Journal of Biogeography 29:1475-1487.

Pastor, J., R.J. Naiman, B. Dewey, and P. McInnes. 1988. Moose, microbes, and the boreal forest. Bioscience 38:770-777.

Persson, I.L., K. Danell, and R. Bergstrom. 2005. Different Moose densities and accompanied change in tree morphology and browse production. Ecological Applications 15:1296-1305.

Peterson, R.O. 1995. The Wolves of Isle Royale: A Broken Balance. Willow Creek Press, Minocqua, WI. 189 pp.

Phillips, R.L., W.E. Berg, and D.B. Siniff. 1973. Moose movement patterns and range use in northeastern Minnesota. Journal of Wildlife Management 37:266-278.

Rea, R.V., and M.P. Gillingham. 2001. The impact of the timing of brush management on the nutritional value of woody browse for Moose, Alces alces. Journal of Applied Ecology 38:710-719.

Renecker L.A., and C.C. Schwartz. 1997. Food habits and feeding behavior. Pp. 403439, In A.W. Franzmann and C.C. Schwartz (Eds.). Ecology and Management of the North American Moose. Smithsonian Institution, Washington, DC. 733 pp.

Ross, P. 1958. Microclimatic and vegetational studies in a cold-wet deciduous forest. Harvard Black Rock Forest Paper No. 24. Cornwall-on-the-Hudson, NY. 89 pp.

Scholes, R.J., and S.R. Archer 1997. Tree-grass interactions in savannas. Annual Review of Ecology and Systematics 28:517-544.

Schwartz, C.C., and L.A. Renecker. 1997. Nutrition and energetics. Pp. 441-478, In A.W. Franzmann and C.C. Schwartz (Eds.). Ecology and Management of the North American Moose. Smithsonian Institution, Washington, DC. 733 pp.

Spurr, S.H. 1956. Forest associations in the Harvard Forest. Ecological Monographs 26:245-262.

Telfer, E.S. 1984. Circumpolar distribution and habitat requirements of Moose. Pp.145-181, In R. Olson, R. Hastings, and F. Geddes (Eds.). Northern Ecology and Resource Management. University of Alberta, Edmonton, AB, Canada. $456 \mathrm{pp}$.

Thompson, I.D., and R.W. Stewart. 1997. Management of Moose habitat. Pp. 377401, In A.W Franzmann and C.C. Schwartz (Eds.). Ecology and Management of the North American Moose. Smithsonian Institution, Washington, DC. 733 pp.

Thompson, I.D., W.J. Curran, J.A. Hancock, and C.E. Butler. 1992. Influence of Moose browsing on successional forest growth on Black Spruce sites in Newfoundland. Forest Ecology and Management 47:29-37. 
Trefethen, J.B. 1953. The Massachusetts land and its wildlife: A history of the resident and migratory game birds and mammals of Massachusetts. M.A. Thesis. University of Massachusetts, Amherst, MA.

University of Connecticut Cooperative Extension Service. 1994-2008. Southern New England stumpage price survey results. Compiled by University of Massachusetts, University of Connecticut, and the state Forestry Agencies of Connecticut, Massachusetts, and Rhode Island. Available online at http://www.canr. uconn.edu/ces/forest/pricesht.htm. Accessed 10 December 2008.

United States Naval Observatory. 2008. Naval Oceanography Portal. Available online at http://aa.usno.navy.mil/data/docs/RS_OneDay.php. Accessed December $5,2008$.

Whitney, G.G. 1994. From Coastal Wilderness to Fruited Plain. Cambridge University, Cambridge, UK. 488 pp.

Zimov, S.A., V.I. Chuprynin, A.P. Oreshko, F.S. Chapin, J.F. Reynolds, and M.C. Chapin. 1995. Steppe-tundra transition: A herbivore driven biome shift at the end of the Quaternary. American Naturalist 146:765-793. 